\title{
Reconnaissance for
}

\section{Radioactive Deposits in the}

Darby Mountains District,

Seward Peninsula, Alaska

By Walter S. West

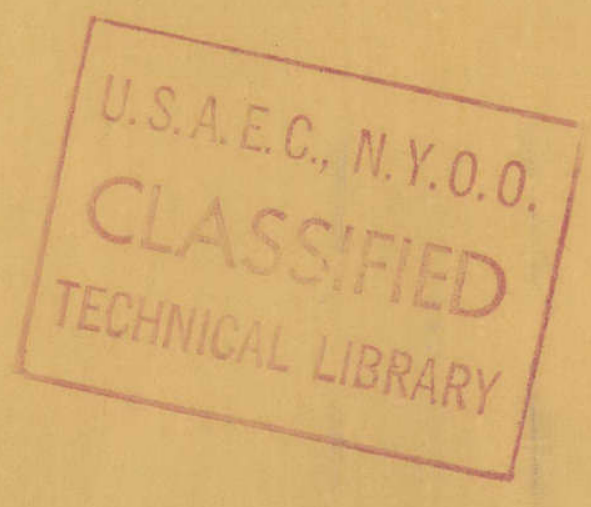

\section{Trace Elem ents Investigations Report 53}

UNITED STATES DEPARTMENT OF THE INTERIOR GEOLOGICAL SURVEY 



\section{UNCLASSIFIED}

Geology - Mineralogy

This document consists of 26 pages, plus 1 figure.

Series A

UNITED STATES DEPARTMENT OF THE INTERIOR

GEOLOGICAL SURVEY

RECONNAISSANCE FOR RADIOACTIVE DEPOSITS

IN THE DARBY MOUNTAINS DISTRICT,

SEWARD PENINSULA, ALASKA*

By

Walter S. West

March 1953

Trace Elements Investigations Report 53

This preliminary report is distributed without editorial and technical review for conformity with official standards and nomenclature . It is not for public inspection or quotation.

*This report concerns work done on behalf of the Division of Raw Materials of the U. S. Atomic Energy Commission 
USGS - TEI Report 53

GEOLOGY - MINERALOGY

Distribution (Series A)

No. of copies

American Cyanamid Company, Winchester............ 1

Argonne National Laboratory . . . . . . . . . . . . . . . 1

Atomic Energy Commission, Washington ............ 2

Battelle Memorial Institute, Columbus .............. 1

Carbide and Carbon Chemicals Company, Y-12 Area ........ 1

Division of Raw Materials, Grants ............... 1

Division of Raw Materials, Denver . . . . . . . . . . . 1

Division of Raw Materials, Hot Springs .............. 1

Division of Raw Materials, New York ............. 6

Division of Raw Materials, Salt Lake City ............. 1

Division of Raw Materials, Richfield. . . . . . . . . . . . 1

Division of Raw Materials, Butte ................ 1

Division of Raw Materials, Washington .............. 3

Dow Chemical Company, Pittsburg . . . . . . . . . . . . . . I

Exploration Division, Grand Junction Operations Office ....... 1

Grand Junction Operations Office .............. I

Technical Information Service, Oak Ridge. . . . . . . . . . . 6

Tennessee Val ley Authority, Wilson Dam ............. 1

Terr. Dept. Mines, Juneau (P. H. Holdsworth) ... . . . . . . I

Terr. Dept. Mines, Ketchikan (A. E. Glover) . . . . . . . . . . 1

Terr. Dept. Mines, College (L. L. Patton) . . . . . . . . . . 1

Terr. Dept. Mines, Nome (D. Jones) . . . . . . . . . . . . . I

U. S. Geological Survey:

Mineral Deposits Branch, Washington . . . . . . . . . . . 1

Geochemistry and Petrology Branch, Washington .......... 1

Geophysics Branch, Washington . . . . . . . . . . . . . 1

Alaskan Geology Branch, Washington ............. 8

Fuels Branch, Washington ................. 1

G. O. Gates, San Francisco ................. 2

L. H. Saarela, Anchorage . . . . . . . . . . . . . . 1

C. L. Sainsbury, Juneau .................. . . I

R. M. Chapman, Fairbanks ................ 1

V. E. McKelvey, Washington................. I

L. R. Page, Denver . . . . . . . . . . . . . . . I I

R. P. Fischer, Grand Junction ................ 1

A. E. Weissenborn, Spokane ................ 1

TEPCO, Washington.................. 5

(Including master) 


\section{CONTENTS}

Page

Abstract $\ldots \ldots \ldots \ldots \ldots$

Introduction $\ldots \ldots \ldots \ldots \ldots \ldots$

Geology ......................... 7

Undivided metamorphic rocks ............... 7

Paleozoic rocks ..................... 8

Greenstone and greenstone schist .............. 8

Undivided igneous complex ................ 8

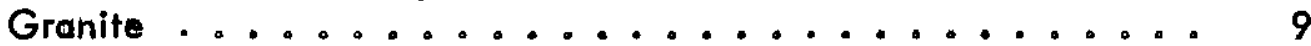

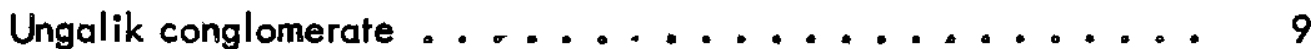

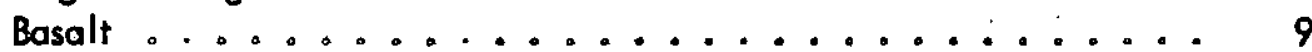

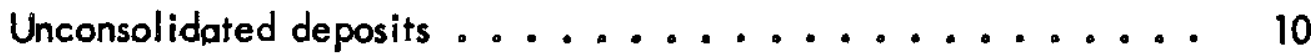

Hot springs ........................... 10

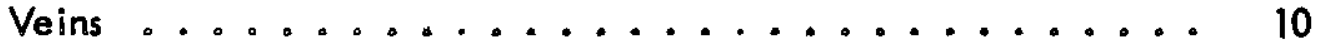

Mineral deposits ........................... 11

Radioactivity investigations ..................... 12

Kachauik Creek-Cheenik Creek area ............. 13

McKinley Creek-Bryan Creek arear ............... 14

Portage Creak-Cape Darby area ............... 15

Norton Bay coastal area between Cape Darby and

the Kwiniuk River................... 18

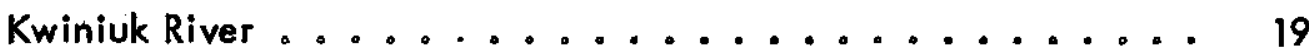

Tubutulik River area ................... 21

Summary and corclusions .................... 24

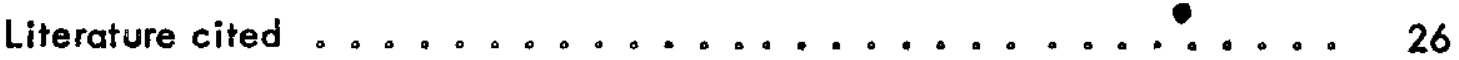

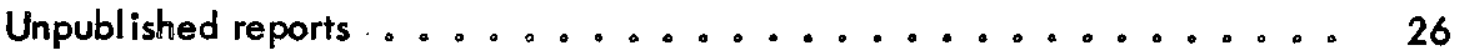

\section{ILLUSTRATION}

Figure 1. Geologic map of the Darby Mountains district, Seward

Peninsula, Alaska ............... in envelope 


\section{TABLES}

Page

Table 1. Mineralogy of selected radioactive heavy-mineral fractions of concentrates from the Portage Creek-Cape Darby area . . . 17

2. Mineralogy of heavy-mineral fractions (greater than $\mathbf{3 . 3}$ specific gravity) of concentrates from the Tubutulik River area ..................... 23 


\title{
RECONNAISSANCE FOR RADIOACTIVE DEPOSITS \\ IN THE DARBY MOUNTAINS DISTRICT, SEWARD PENINSULA, ALASKA \\ By Walter S. West
}

\begin{abstract}
Radioactivity in the Darby Mountains district of the Seward Peninsula, Alaska, appears to be directly related to the occurrence of granite. Concentrates from placers derived from areas containing granite are more radioactive than concentrates from placers not derived from the granite and, generally, contain from 0.01 to 0.05 percent equivalent uranium. The radioactivity of these concentrates is largely due to radioactive elements in common aceessory minerals in granite, such as sphene, allanite, and zircon, and locally, monazite Locally, in the Clear Creek-Vulcan Creek area, the headwaters of the Kwiniuk River, and on Golovin Bay near McKinley Creek, concentrates from placers derived from granitic terrain contain as much as 0.1 percent equivalent uranium. The higher radioactivity of the concentrates from the Clear Creek area and on Golovin Bay is due chiefly to an unidentified uraniumtitanium niobate, whereas the higher radioactivity at the headwaters of the Kwiniuk River is due to thorianite.
\end{abstract}

\section{INTRODUCTION}

The Darby Mountains district is situated in the southeastern part of the Seward Peninsula, Alaska (fig. 1). The Darby Mountains have a general north-south trend and extend from Cape Darby on the south to the southeastern portion of the Bendeleben 
Mountains on the north, a distance of approximately 75 miles. The area is bounded on the west by Golovin Sound, Golovin Bay, and the Fish River and in general on the east by Norton Bay and the Tubutulik River, although the upper half of the latter river dissects the eastern flank of the mountains

The area is accessible from Nome, approximately 70 miles to the west, by air to two small airstrips, one located at Golovin on the western side of the Darby Peninsula and the other at White Mountain on the Fish River and the Moses Point Civil Aeronautics Authority airfield near the mouth of the Kwiniuk River, 46 miles northeast of Golovin. There are no good harbors along the entire coast. Transportation of supplies within the area must be accomplished by tractor or in part by small boats, as there are no roads.

The Darby Mountains are a relatively tow range with the highest peaks seldom rising to over 3,000 feet above sea levet. In the heart of the range glaciation has produced cirques and steep-sided, U-shaped valleys. Some streams have cut deep valleys. Wave action along the southern coast of the Darby Peninsula has produced a rugged coast with high cliffs and a beach so slightly developed that it is impossible to walk along the shore in many piaces.

The greater part of the Darby Mountains district is made up of well rounded tundra- or vegetation-covered hills and mountains. Rock pinnacles, talus, and rock fragments occur on and near the tops of many mountains, but bedrock outcrops are surprisingly scarce 。

Previous investigations (Gault, Black, Lyons, 1946; Killeen and White, 1950; and West and Matzko, 1952) in the Buckland-Kiwalik district to the northeast of the Darby Mountains revealed the presence of uranothorianite and several other 
less radioactive minerals widtly distributed, but locally concentrated, in areas underlain by felsic igneous rocks. The purpose of the 1948 reconnaissance in the Darby Mountains was to determine whether similar radioactive minerals also occur in the felsic igneous rocks of this district, and, if present, attempt to discover any sites of high concentration and the bedrock source of such minerals. The reconnaissance was conducted during the summer of 1948 by a field party consisting of W. S. West, geologist, and $A_{0}$ E. Nessett, J. J. Otoyuk, and I. M. Ikleasik, camp assistants. Time permitted only the investigation of the southern and eastern parts of the district. The route followed is indicated by the location of camps, numbered in chronologic order starting at Golovin, on figure 1.

\section{GEOLOGY}

The only work of the Geological Survey in the Darby Mountains district prior to this investigation was done by two parties, those of Mendenhall (1901), who in 1900 mapped both topographically and geologically she Koyuk River valley and parts of the Darby Mountains on an exploration-reconnaissance scale; and of Smith and Eakin (1911), who in 1909 mapped the area between Nulato and Council on a similar scale.

The geologic features of the Darby Mountains district are described briefly below。

Undivided metamorphic rocks

The oldest rocks in the district occur mainly along the western flanks of the Darby Mountains and are the folded and sheared metamorphic rocks of pre-Silurian and possibly pre-Cambrian age (fig. 1). These rocks consist of quartzose, calcareous, 
biotitic, chloritic, feldspathic, and graphitic schist and thin limestones. The schist has been cut by greenstone, granite, diorite, and ather igneous rocks which have had a share in the metamorphism and obliteration of the original characters of the schist.

\section{Paleozoic rocks}

Paleozoic rocks of Carboniferous, Devonian, and Silurian age are best represented along the eastern flank of the Darby Mountains and are well exposed along the sea coast from the mouth of Iron Creek southeast nearly to Carson Creek. This group of rocks, composed mainly of limestone with subordinate dolomite, black slate, and schist, is complexly folded, faulted, metamorphosed, and cut by intrusives of greenstone, granite, and diorite.

\section{Greenstone and greenstone schist}

The post-Carboniferous greenstone and greenstone schist, which occur along the eastern flank of the Darby Mountains, were not observed in place, although greenstone cobbles and pebbles were seen on the bars along the lower course of the Tubutulik River 。

\section{Undivided igneous complex}

An undivided igneous complex and the granite make up the central core of the Darby Mountains. The undivided igneous complex is believed to belong to one geologie body of pre-Cretaceous age. It is composed mainly of granite, which has undergone varying degrees of metamorphism, but also includes some diorite, greenstone, and several other types of igneous rocks whose characteristics are not suffi- 
ciently clear to allow their identification and subdivision.

\section{Granite}

The granite, also pre-Cretaceous in age, ranges from even-grained to porphyritic texture and exhibits considerable variation in mineralogical composition. in the area studied the porphyritic granite is much more abundant than the even-grained granite. Outcrops usually take the form of knobs and pinnacles on the tops and sides of the mountains. Inclusions of diorite in the porphyritic granite noted especially along the east coast of the Darby Peninsula indicate that the granite is younger than some of the diorites in the undivided igneous complex.

\section{Ungalik conglomerate}

The Ungalik conglomerate, the oldest formation of the Cretaceous sedimentary sequence in west-central Alaska, is made up of rounded debris derived from older formations including limestone, schist, igneous rocks, quartz veins, and sandstone. It forms the divide between the Tubutulik and Kwik rivers on the extreme eastern flank of the Darby Mountains. One outcrop of this conglomerate was noted along the bank of the lower Tubutulik River.

\section{Basalt}

Two isolated outcrops of vesicular basalt of Tertiary age were observed in the area. One lies between the headwaters of Grouse Creek and the Twbutulik River and the other between the third and fourth east tributaries to the Right Branch of Kachauik Creek (fig。1). 
Unconsolidated deposits

The youngest deposits shown on figure 1 are the marine and non-marine waterlaid deposits of Quaternary age. No attempt has been made to show the glacial deposits nor the widespread deposits of unsorted waste rock that cover practically all of the area not occupied by marine and non-marine gravels, sands, and silts.

\section{Hot springs}

A hot spring, not mentioned in earlier Survey literature, was discovered issuing from granite high on a mountain slope above Clear Creek, a right tributary to the Tubutulik River. The stream formed by this spring constitutes the seventh west tributary to Clear Creek above the latter's mouth (fig. 1). Another hot spring occurs on the north side of the Kwiniuk River in the vicinity of the mouth of Corral Creek. The spring was not visited, but it is also believed to issue from granite.

\section{Veins}

Quartz and calcite veins and veinlets are abundant in the schistose rocks, and calcite veins are common in the limestones. Quartz veins also occur in the granite and granitoid rocks, but they are much less common than in the schists. About 2 miles north of Golovin along the beach a large quirtz lens $30-$ by $15-$ by 10 -feet may be seen, but this lens, like practically all of the veins and veinlets, contains no sulfides. Half a mile north of this lens, vein quartz containing chalcopyrite was found in float along the beach, and chalcopyrite-quartz ve in float, stained and incrusted with malachite, was observed on the west bank of the Right Branch of Kachauik Creek about 75 yards upstream from the mouth of the second east tributary. Iron-stained 
quartz and calcite veins were observed at other localities, and some veins have been reported by prospectors to carry small quantities of gold.

\section{Mineral deposits}

No lode mines were operating in the Darby Mountains district during 1948. There is evidence that lode prospecting, probably for copper and gold, has been carried on in the past along the coast of Norton Bay between Carson and Walla Walla Creeks, but n๑ deposits of economic importance were discovered. The only lode prospect of any significance in the enfire Darby Mountain district is a silver-lead prospect on Omilak Creek, a tributary to the Fish River, in the northwestern part of the Darby Mountains, but this prospect was not visited.

A coal deposit, not previously mentioned in Survey literature, was found to crop out on the right headwaler fork of the left branch of Grouse Creek, a tributary to the Tubutulik River. This deposit appears to have an east-west extent of over 1 mile, and the outcrop from stream level to the top of the bank varies from 10 to 15 feet in thickness although the depth of the coal below the level of the stream is not known. The coal is probably a high-grade lignite and may possibly rank as high as subbituminous $C$ coal .

There is no evidence of any recent placer mining in the district, and no one was prospecting during the summer of 1948 . The only old placer-gold operation observed was on Grouse Creek. In the past gold prospecting has been done on Vulcan, Chukajak, and Admiral creeks, all tributaries to the Tubutulik River. 


\section{RADIOACTIVITY INVESTIGATIONS}

The instrument used for field radiometry in the Darby Mountains district was a standard commercial model of a portable survey meter with a 6-inch beta-gamma probe. Because the greater part of the district is covered with vegetation, mostly tundra, and talus, direct radiometric testing of outcrops was, of necessity, limited in scope, and the low sensitivity of the probe rendered the instrument ineffectual for traversing. To study effectively distribution of radioactive minerals in the district the greater part of the field work was directed, therefore, to the collection of concentrates from slope wash and the gravels of stream and beach deposits in an effort to determine whether radioactive minerals were being concentrated in placers formed by the deposition of material eroded from rocks in the various drainage areas. Thus, local concentrations of radioactive minerals could be found, the ultimate source of which could then be discovered by trenching to bedrock at selected localities .

In the course of the season a total of 248 concentrates were collected from 215 sites of stream gravels, 20 sites of beach gravels, and 13 sites in slopewash. Each concentrate from stream and beach gravels was panned from about 50 pounds of sand and gravel, and each slopewash concentrate was panned from approximately 100 pounds of disintegrated rock material. The locations of these concentrates are shown on figure 1. Each of these concentrates was tested for radioactivity in the field to determine whether additional concentrates should be taken in any given drainage area. For consistency in expressing the radioactivity of these concentrates, each sample was further concentrated in the laboratory by separating the light-and heavy-mineral fractions with bromoform (specific gravity 2.89). As preliminary tests showed that essentially all the radioactive minerals occur in the heavy fraction, the equivalent uranium 
content of each heavier-than-bromoform fraction was then determined by radiometric analysis. To concentrate further the radioactive minerals for mineralogic study the heavier-than-bromoform fractions of selected concentrates were subdivided into light and heavy sub-fractions by using methylene iodide (specific gravity 3.3 ), as again preliminary scanning of the samples indicated that essentially all the radioactive minerals have a relatively high specific gravity.

In addition to the above technique of testing areas by studying the heavymineral content of its placers, the writer collected numerous rock samples, mostly float rock from talus slopes and stream gravels. However, as the radioactivity of none of these samples was estimated to exceed 0.003 percent equivalent uranium when tested with the portable survey meter, they were not examined in more detail.

The distribution of radioactivity in the Darby Mountains district is discussed by area below.

\section{Kachauik Creek-Cheenik Creek area}

The rocks in the drainage basins of Kachavik and Cheenik Creeks (fig. 1) include two bodies of granite, which appear to be the source rocks of the radioactive minerals in the concentrates collected from the area. The distribution of radioactivity in a total of 46 concentrate samples (nos. 2834-2889, fig. 1) obtained in the area is as follows:

$\begin{array}{cc}\begin{array}{c}\text { Range in equivalent uranium } \\ \text { content (percent) }\end{array} & \text { No. of samples } \\ & \\ \text { Less than } 0.01 & 25 \\ 0.01 \text { to } 0.02 & 14 \\ \text { More than } 0.02 & 7 \\ \text { (maximum } 0.028 \text { ) } & \end{array}$


All the concentrates containing 0.01 pereent or more equivalent uranium are from those parts of the two main streams or their tributaries which drain the granite bodies. The concentrates that contain more than 0.02 percent equivalent uranium have an average concentration ratio of about $360 \% 1$.

The mineral fraction greater than 3.3 specific gravity of sample 2839 , selected as typical of the radioactive concentrates from the Kachauik Creek-Cheenik Creek area, contains, in decreasing order of abendance: hornblende, sphene, garnet, and zircon and traces of magnetite, ilmenite, and olivine. Although the radioactive minerals in this sample were not specifically identified, it is likely that the radioactive elements occur chiefly in the sphene and zircon.

\section{McKinley Creek-Bryan Creek area}

In the McKinley Creek-Bryan Creek area (fig. 1) a small body of granite occurs in the headwaters of Bryan Creek and an even smaller body appears in a sea cliff on Golovin Sound about midway between the mouths of Cheenik and McKinley Creeks. Six concentrates (nos.2893-2898) were taken in the vicinity of the granite at the head of Bryan Creek. The radioactivity of these concentrates, which have concentration ratios of 500 to $1,000: 1$, ranges from 0.009 to 0.015 percent equivalent uranium. The radioactive mineral in these samples were not identified but are believed to be one or more of the common accessory minerals in the granite. Sample 2890, a concentrate taken from a mall unnamed stream, not shown in figure 1, contains 0.016 percent equivalent uragium. As this stream probably heads in the edge of the granite on upper Bryan Creek and the radioactivity and concentration ratio is about the same as the somples from Bryan Creek, it is likely that radioactive minerals 
are the same as those in the samples from Bryan Creek.

The material in the slopewash concentrate (sample 2891) taken at the granite on the coast between Cheenik and McKinley Creeks is believed to have been derived mostly from a mineralized zone near the contact between the granite and the older igneous complex (fig. 1). The heavier-than-bromoform fraction contains 0.074 percent equivalent uranium. The minerals of more than 3.3 specific graxity are chiefly magnetite, with lesser amounts of sphene and topaz, and minor amounts of allanite, hematite, ilmenite, hornblende, biotite, scheelite, and an unidentified uraniumtitanium niobate mineral. The uranifepous niobate is the chief radioactive mineral, although radioactive elements in the allanite, hematite, and sphene doubtless contribute to the total radioactivity of the sample.

\section{Portage Creek-Cape Darby area}

Between Portage Creek and Cape Darby 24 concentrate samples (nos. 28992922, fig. 1) were collected to determine whether radioactive minerals were being eroded from the rocks along the numerous short streams and sea cliffs in the area. The distribution of radioactivity in these samples follows:

$\begin{array}{cr}\begin{array}{c}\text { Range in equivalent uranium content } \\ \text { (percent) }\end{array} & \text { No. of } \\ \text { Less than } 0.01 & 17 \\ 0.01-0.02 & 2 \\ \text { More than } 0.02 & 5\end{array}$

Data on the concentrates from this area containing 0.01 percent or more equivalent uranium are given as follows. 


\begin{tabular}{cccc} 
Sample no. & Location & $\begin{array}{c}\text { Percent equivalent } \\
\text { uranium }\end{array}$ & Concentration ratio \\
\cline { 1 - 1 } 2899 & Portage Creek, near mouth & 0.022 & $650: 1$ \\
2890 & Portage Creek, right tributary & .034 & $550: 1$ \\
2905 & $\begin{array}{l}\text { Golovin Sound beach near } \\
\text { Mission Creek }\end{array}$ & .015 & $75: 1$ \\
2909 & $\quad$ do. & .015 & $130: 1$ \\
2910 & $\quad$ do. & .030 & $30: 1$ \\
2918 & $\begin{array}{l}\text { Unnamed stream entering } \\
\text { Golovin Sound about 3-1/2 } \\
\text { miles south of Mission Creek }\end{array}$ & .035 & $6,400: 1$ \\
& $\begin{array}{l}\text { Golovin Sound sea cliff about } \\
4-1 / 2 \text { miles south of Mission } \\
\text { Creek }\end{array}$ & .049 & $1,200: 1$ \\
& &
\end{tabular}

The mineralogy of selected radioactive samples from the Portage Creek-Cape Darby area is given in table 1. As in the Kachauik Creek-Cheenik Creek area the more radioactive samples are concentrates in which the material has been derived chiefly from granite.

In this area the radioactivity is due to the presence of radioactive elements in allanite, hematite, and monazite as well as sphene and zircon. Of particular note is the slopewash concentrate (sample 2918) from the small granite mass about 4 miles south of Mission Creek which contains chiefly hematite and topaz. The material from which this concentrate was obtained consisted largely of disintegrated rock from a contact zone between the younger granite and the older intrusives, in this case a metamorphosed granitic rock. The possibility that the radioactive elements, particularly uranium, in this area were introduced hydrothermally in a late stage of the consolidation of the granite magmas; is suggested by the occurrence of fluorite and topaz. 
Table 1.--Mineralogy of selected heavy-mineral fractions- of concentrates from the Portoge Creek-Cape Darby area.

\begin{tabular}{|c|c|c|c|c|}
\hline & 2900 & 2910 & 2918 & 2921 \\
\hline Fluorite & $x^{2}-$ & - & -- & tr \\
\hline Hematite & $\operatorname{tr}$ & $x$ & $x$ & $x$ \\
\hline Ilmenite & $\operatorname{tr}$ & $x$ & -- & $x$ \\
\hline Spinel & -- & $x$ & -- & -- \\
\hline Magnetite & $x$ & $x$ & -- & $x$ \\
\hline Rutile & - & $x$ & -- & -- \\
\hline Hornblende & $x$ & -- & - & - \\
\hline Garnet & $x$ & $x$ & -- & $x$ \\
\hline Olivine & -- & tr & - & -- \\
\hline Zircon & $x$ & $x$ & tr & $x$ \\
\hline Topaz & -- & - & $x$ & -- \\
\hline Epidote & - & $x$ & -- & tr \\
\hline Allanite & $x$ & - & -- & tr \\
\hline Staurolite & -- & $x$ & -- & -- \\
\hline Biotite & -- & -- & -- & $\operatorname{tr}$ \\
\hline Sphene & $x$ & $x$ & - & - \\
\hline Monazite & -- & -- & -- & $x$ \\
\hline Scheelite & - & -- & -- & tr \\
\hline Powellite & -- & tr & -- & -- \\
\hline
\end{tabular}


Norton Bay coastal area between Cape Darby and the Kwiniuk River

Twenty-seven concentrates (samples 2923-2946 and 2963-2965, fig. 1) were taken in the coastal area along Norton Bay between Cape Darby and the mouth of the Kwiniuk River. These include three samples from the area of a granite at the head of the Kwiniuk River, which extends to within several miles of the coast about 13 miles north of Cape Darby (fig. 1). Most of the concentrates were collected in the vicinity of several small granite bodies that occur along the coast in the vicinity of Carson Creek. The radioactivity data of the 27 concentrates are summarized as follows:

Range in equivalent uranium content (percent)

No. of samples

Less than 0.01

$0.01-0.02$

More than 0.02 5

Pertinent datd on the heavy-mineral fractions of samples containing more than 0.02 percent equivalent uranium follow:

\begin{tabular}{|c|c|c|c|}
\hline Sample no. & Location & $\begin{array}{l}\text { Percent equivalent } \\
\text { uranium }\end{array}$ & $\begin{array}{c}\text { Concentration } \\
\text { ratio } \\
\end{array}$ \\
\hline 2927 & $\begin{array}{l}\text { Creek between Norton Bay, } 2.8 \text { miles } \\
\text { south of Carson Creek }\end{array}$ & 0.021 & $410: 1$ \\
\hline 2929 & $\begin{array}{l}\text { Creek between Norton Bay, } 0.6 \text { miles } \\
\text { south of Carson Creek }\end{array}$ & .024 & $560: 1$ \\
\hline 2937 & Carson Creek & .024 & $380: 1$ \\
\hline 2963 & $\begin{array}{l}\text { Headwaters Kwiniuk River, second right } \\
\text { tributary below headwater forks }\end{array}$ & .029 & $350: 1$ \\
\hline 2965 & Headwaters of Kwiniuk River & .039 & 410:1 \\
\hline
\end{tabular}

Although the radioactive minerals in the concentrates from the Norton Bay coastal area were not identified (except for one concentrate from the head of the Kwiniuk River), the fact that the locations of the more radioactive samples are directly related to location of the granites suggests that the bulk of the radioactivity is due to common 
accessory minerals of the granite, such as zircon and sphene. However, because of the proximity of these granites to those on the west side of the Darby Peninsula in the vicinity of Mission Creek, it is also possible that such minerals as allanite and monazite might also be found in these concentrates and, if so, contribute to the radioactivity of the samples.

Sample 2965 from the granite area near the head of the Kwiniuk River (fig. 1), contains, in decreasing order of abundance, hornblende, sphene, zircon, garnet, hematite, magnetite, epidote, olivine, and thorianite. The thorianite is the chief radioactive mineral; however, the zircon and sphene are slightly radioactive. Although the bedrock occurrence of the thorianite is most likely as an accessory mineral in the granite, the proximity of the contact between the granite and metamorphosed sedimentary rocks, including limestone, suggests that the thorianite may well have been derived from altered rocks in the contact zone.

\section{Kwiniuk River}

The Kwiniuk River crosses a large belt of granite about half way to its headwaters (fig. 1). Unfortunately the investigation of this granite area could not be completed because of the onset of cold weather in the fall. However, some 16 concentrates (samples 2947-2962) were taken along the Kwiniuk, and a few of its tributaries, between its mouth and the belt of granite. The equivalent uranium content of the heavy-mineral fractions (those greater than 2.89 specific gravity) of these concentrates are given as follows. 


\begin{tabular}{|c|c|c|c|}
\hline Sample no. & $\begin{array}{c}\text { Percent equivalent } \\
\text { uranium } \\
\end{array}$ & Concentration ratio & Remarks \\
\hline 2947 & 0.003 & $1,080: 1$ & \\
\hline 2948 & .008 & 120: 1 & \\
\hline 2949 & .008 & 250:1 & \\
\hline 2950 & .015 & $180: 1$ & \\
\hline 2951 & .011 & $310: 1$ & \\
\hline 2952 & .018 & $210: 1$ & \\
\hline 2953 & .002 & $610: 1$ & Right-limit tributary \\
\hline 2954 & .012 & 240: 1 & \\
\hline 2955 & .006 & $330: 1$ & Left-limit tributary \\
\hline 2956 & .004 & 240: 1 & Do. \\
\hline 2957 & .015 & $180: 1$ & \\
\hline 2958 & .011 & 250: 1 & \\
\hline 2959 & .013 & $210: 1$ & \\
\hline 2960 & .015 & $230: 1$ & \\
\hline 2961 & .017 & 230:1 & Left-limit tributary \\
\hline 2962 & .017 & $180: 1$ & \\
\hline
\end{tabular}

As seen in the above tabulation and on figure 1 the equivalent uranium content of the samples has a fairly general increase in upstream order with the radioactivity confined almost entirely to concentrates from the main stream. Although the equivalent uranium content of the concentrates is not as relatively high when compared to other concentrates from the district, the general increase upstream suggests that higher values might be obtained in the granite belt, which is believed to be the chief source of the radioactive minerals. The heavy minerals in sample 2961 , which was obtained from a small tributary draining a small part of the granite along its contact with adjacent Paleozoic sedimentary rocks (fig. 1), are chiefly sphene, hornblende, allanite, apatite, hematite, and garnet; also found were traces of spinel, scheelite, powellite, magnetite, epidote, rutile, pyrite, and chalcopyrite. The radioactivity of the sample is ascribed mostly to thorium in the allanite, although it is likely that some of the other minerals, such as the sphene and hematite, are also radioactive. The presence of traces of scheelite, powellite, and chalcopyrite suggests that at least some of the minerals in the concentrate were derived from some type of lode at or near the contact 
between the granite and the Paleozoic limestone and shale. It is possible, therefore, that some, if not all, of the radioactive minerals might also have been derived from a lode source rather than have originated as accessory minerals in the granite.

\section{Tubutulik River area}

The drainage basin of the Tubutulik River is underlain by a large variety of rock types (fig. 1). The most significant feature, however, is a wide belt of granite along the western side of the area that is a continuation of the granite belt crossing the Kwiniuk River to the south. Of a total of 114 concentrates (samples 2966-2990, 2991-2998, and 3000-3002, 3004, 3081, fig. 1) 41 contain between 0.01 and 0.02 percent equivalent uranium, and 34 contain more than 0.02 percent equivalent uranium up to a maximum of about 0.1 percent equivalent uranium. The radioactivity of the concentrates from the Tubutulik River and its tributaries is confined entirely to samples in which at least part of the original material concentrated was derived from granitic rocks (fig. 1). In general, the equivalent uranium content of the concentrates increases as the streams are ascended to and within the granite. The data on the concentrates from the Tubutulik River area that contain more than 0.02 percent equivalent uranium are given below; the location of these samples are arranged in order from south to north, rather than in upstream order, in an attempt to show more precisely the relationship of the radioactivity of the concentrates to the belt of granite.

\begin{tabular}{|c|c|c|c|}
\hline Sample no. & Location & $\begin{array}{c}\text { Percent equivalent } \\
\text { uranium }\end{array}$ & $\begin{array}{c}\text { Concentration } \\
\text { ratio }\end{array}$ \\
\hline 3020 & $\begin{array}{l}\text { Seventh west tributary of Clear Creek, } \\
\text { near Hot Spring }\end{array}$ & 0.038 & 375:1 \\
\hline 3021 & do. & .022 & 200:1 \\
\hline 3009 & Third west tributary of Clear Creek & .022 & 425:1 \\
\hline
\end{tabular}




\begin{tabular}{|c|c|c|c|}
\hline Sample no. & Perce & $\begin{array}{l}\text { ent equivalent } \\
\text { uranium }\end{array}$ & $\begin{array}{l}\text { Concentration } \\
\text { ratio }\end{array}$ \\
\hline 2983 & $\begin{array}{l}\text { Second west tributary of Clear } \\
\text { Creek }\end{array}$ & 0.086 & $1,100: 1$ \\
\hline 2984 & do. & .023 & 400:1 \\
\hline 2987 & dc。 & .027 & $1,750: 1$ \\
\hline 2988 & do. & .067 & $2,200: 1$ \\
\hline 2989 & do. & .054 & $1,050: 1$ \\
\hline 2990 & do. & .027 & 475: 1 \\
\hline 2992 & do. & .104 & $1,850: 1$ \\
\hline 2993 & do. & .079 & $1,450: 1$ \\
\hline 2994 & do. & .060 & $750: 1$ \\
\hline 2995 & do. & .066 & $1,900: 1$ \\
\hline 2996 & do. & .065 & $1,550: 1$ \\
\hline 2997 & do. & .040 & $1,500: 1$ \\
\hline 2982 & Clear Creek & .022 & $n_{0} d$ \\
\hline 2974 & First west tributary to Clear Creek & .023 & $600: 1$ \\
\hline 2975 & do. & .023 & $925: 1$ \\
\hline 2979 & do. & .023 & $4,000: 1$ \\
\hline 3028 & Vulcan Creek & .048 & 275: 1 \\
\hline 3029 & do. & .027 & $127: 1$ \\
\hline 3030 & do. & .042 & 825:1 \\
\hline 3031 & do. & .044 & $1,850: 1$ \\
\hline 3032 & do. & .043 & $1,450,1$ \\
\hline 3033 & do. & .067 & $1,050: 1$ \\
\hline 3034 & do. & .023 & 725:1 \\
\hline 3035 & do. & .025 & 450:1 \\
\hline 3052 & Rock Creek & .036 & $2,250: 1$ \\
\hline 3072 & $\begin{array}{l}\text { First south tributary to Tubutulik } \\
\text { River above Rock Creek }\end{array}$ & .024 & $1,450: 1$ \\
\hline 3075 & Big Creek & .023 & $1,200: 1$ \\
\hline 3077 & $\begin{array}{l}\text { First northeast tributary to Tubutu- } \\
\text { lik River above Grouse Creek }\end{array}$ & .046 & \\
\hline 3078 & $\begin{array}{l}\text { Second northeast tributary to Tubu- } \\
\text { tulik River above Grouse Creek }\end{array}$ & .055 & $1,500: 1$ \\
\hline 3064 & Grouse Creek & .076 & $2,750: 1$ \\
\hline
\end{tabular}

From the above tabulation it is apparent that three major centers of abnormal radioactivity occur in the Tubutulik River area. These centers are on the second west tributary of Clear Creek, on Vulcan Creek, and in the orea between Grouse Creek and the Tubutulik River. The mineral composition of representative concentrates from these areas are given in table 2. For comparison, the mineral composition for radioactive 
Table 2.--Mineralogy of heavy-mineral fractions (greater than 3.3 specific gravit $y$ ) of concentrates from the Tubutulik River area.

\begin{tabular}{|c|c|c|c|c|c|c|c|c|c|c|c|c|c|c|}
\hline Sample no. & ষ্ণ & 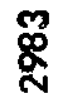 & $\underset{\mathbb{N}}{\stackrel{\mathbb{N}}{*}}$ & $\underset{\sim}{\stackrel{2}{\alpha}}$ & $\stackrel{\mathfrak{2}}{\stackrel{\alpha}{\alpha}}$ & $\underset{\sim}{\stackrel{\circ}{\alpha}}$ & $\underset{\stackrel{N}{N}}{\stackrel{+}{N}}$ & ণ্ণ్లి & ల్లి & గ్రి & 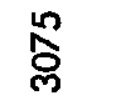 & S & $\stackrel{\infty}{\stackrel{\infty}{S}}$ & ষ্ঠ \\
\hline Pyrrhotite & -- & - & -- & -- & -- & -- & -- & -- & -- & -- & $\operatorname{tr} 1 /$ & -- & - & - \\
\hline Pyrite & tr & - & $x$ & -- & -- & $x$ & $\operatorname{tr}$ & tr & $x$ & -- & tr & - & -- & -- \\
\hline Hematite & -- & $x$ & - & $x$ & $x$ & $x$ & -- & $x$ & $x$ & $x$ & $x$ & -- & $\mathrm{x}$ & -- \\
\hline limenite & $\operatorname{tr}$ & $x$ & - & $x$ & $x$ & -- & $x$ & $x$ & -- & $x$ & $x$ & $x$ & $x$ & $x$ \\
\hline Magnetite & $\mathrm{X}$ & -- & -- & $X$ & $\mathrm{x}$ & $X$ & $x$ & $X$ & $x$ & $\mathrm{x}$ & -- & $x$ & $\mathrm{X}$ & 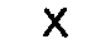 \\
\hline Cassiterite & -- & tr & -- & -- & -- & -- & -- & -- &.$- \cdot$ & -- & -- & -- & -- & -- \\
\hline Rutile & -- & -- & -- & -- & -- & -- & -- & $\operatorname{tr}$ & -- & -- & tr & - & $\mathrm{X}$ & -- \\
\hline Anatase & $\operatorname{tr}$ & -- & -- & -- & -- & tr & tr & $\operatorname{tr}$ & $\operatorname{tr}$ & $x$ & tr & - & $x$ & -- \\
\hline Hornblende & -- & -- & -- & -- & -- & -- & $x$ & tr & - & -- & -- & - & -- & -- \\
\hline Garnet & -- & $x$ & -- & -- & -- & -- & -- & $\operatorname{tr}$ & -- & $x$ & $x$ & -- & -- & $x$ \\
\hline Olivine & -- & -- & -- & -- & -- & -- & -- & -- & -- & -- & $x$ & -- & -- & -- \\
\hline Zircon & $x$ & -- & $\operatorname{tr}$ & -- & - & $x$ & -- & $x$ & $x$ & -- & tr & -- & -- & -- \\
\hline Topaz & $x$ & $x$ & $X$ & -- & -- & $x$ & $x$ & -- & -- & $x$ & - & - & -- & -- \\
\hline Kyanite & -- & -- & -- & -- & -- & -- & -- & $\operatorname{tr}$ & -- & $x$ & -- & -- & -- & -- \\
\hline Epidote & -- & -- & -- & -- & -- & -- & -- & $x$ & -- & $x$ & $x$ & - & $x$ & - \\
\hline Allanite & $x$ & $x$ & $x$ & $x$ & $X$ & $X$ & tr & - & $\operatorname{tr}$ & $x$ & $x$ & -- & -- & -- \\
\hline Staurolite & -- & -- & - & - & - & -- & -- & $x$ & -- & -- & -- & -- & -- & -- \\
\hline Biotite & -- & -- & -- & $-\infty$ & -- & -- & $\operatorname{tr}$ & -- & -- & -- & -- & - & -- & -- \\
\hline Sphene & $x$ & $x$ & $x$ & $x$ & tr & $x$ & $x$ & $x$ & $x$ & $x$ & $x$ & $x$ & $x$ & $x$ \\
\hline Niobate minerals 2 & -- & $\mathrm{x}$ & tr & $\operatorname{tr}$ & -- & $\mathrm{x}$ & -- & -- & $x$ & -- & - & - & $-\infty$ & -- \\
\hline Apatite & -- & -- & $-\infty$ & -- & -- & -- & - & $x$ & -- & -- & -- & - & - & -- \\
\hline Scheelite & -- & tr & -- & -- & -- & -- & -- & -- & -- & -- & -- & - & -- & - \\
\hline Powellite & -- & -- & -- & -- & - & -- & - & - & -- & - & $\operatorname{tr}$ & - & -- & - \\
\hline Wulfenite & $-\infty$ & -- & -- & -- & -- & -- & -- & -- & -- & -- & - & -- & tr & -- \\
\hline
\end{tabular}

1) Those greater than 3.3 specific gravity ( $X$ indicates presence of mineral; tr indicates presence of only traces of the mineral)

2) Unidentified minerals that contain chiefly niobium, titarium, calcium, and uranium 
concentrates of the seventh and first west tributaries of Clear Creek, Rock Creek, and Big Creek are also given.

Review of the above mineral lists suggests that some of the radioactivity in all the concentrates is due to radioactive elements in such minerals as hematite, allanite, and sphene. It is likely that the zircon also is radioactive. Of the more radioactive samples, namely those containing more than 0.06 percent equivalent uranium, only one (that from Grouse Creek) is not from the area between the second west tributary of Clear Creek and Vulcan Creek. The higher radioactivity in the Clear Creek-Vulcan Creek samples is attributed primarily to the presence of an as yet unidentified uraniferous titanium niobate mineral or minerals. The heavy-mineral fractions (greater than 2.89 specific gravity) of samples 2983,2996 , and 3033 were estimated to contain as much as 5 to 10 percent of the niobate mineral or minerals. Qualitative spectrographic analyses of the niobates from these three samples showed that the chief elements in the mineral are niobium, uranium, titanium, and calcium. Traces of silicon and iron were also found. In only one of the samples was a niobate mineral thorium-bearing.

The relatively high radioactivity of the sample from Grouse Creek is ascribed to the occurrence of a large amount of sphene and the relatively high concentration ratio.

\section{SUMMARY AND CONCLUSION}

The widespread cover of vegetation, mostly tundra, and talus in the Darby Mountains district necessitated the use of a placer-sampling technique to evaluate adequately the potentialities of the district for radioactive materials. Field studies and the radiometric analysis and mineralogic study of the heavy-mineral fractions of 
numerous concentrates from placers of the district showed that essentially all the radioactive minerals in the district occur in or were derived from bodies of felsic igneous rocks, chiefly granite .

The most common and widespread radioactive minerals are sphene, allanite, nematite, and zircon. These minerals, with the possible exception of the hematite, are all believed to be primary accessory minerals in the granite. Locally in the Clear Creek-Vulcan Creek area and near the mouth of McKinley Creek, abnormally high radioactivity of concentrates derived from the granite appears to be due to the presence oí a uraniferous titanium niobate mineral. Monazite was identified in one concentrate from the east shore of Golovin Bay between Cape Darby and Portage Creek. Thorianite is the chief radioactive mineral in a concentrate from the head of the Kwiniuk River. Although it is likely that the uranium-and thorium-bearing minerals in the Darby Mountains district are largely disseminated in the granite, local concentrations of the radioactive elements may have formed through hydrothermal activity in a late stage of consolidation of the granite magmas. This is suggested by the common association of topaz, and locally, fluorite, with the radioactive minerals. The association of topaz and traces of cassiterite with the uraniferous niobate mineral in the Clear Creek-Vulcan Creek area suggests also that these minerals may be genetically related to lode tin occurrences or pegmatitic phases of the granite. 


\section{LITERATURE CITED}

Mendenhall, W. Ca, 1901, A reconnaissance in the Norton Bay region, Alaska (In Reconnaissance in the Cape Nome and Norton Bay region, Alaska): U. S. Geol. Survey Special Publication.

Smith, P. S., and Eakin, H. M., 1911, A geologic reconnaissance in southeastern Seward Peninsula and the Norton Bay-Nulato region, Alaska: U.S.Geol. Survey Bull. 449.

\section{UNPUBLISHED REPORTS}

Gault, H. R., Black, R. F., and Lyons, J. B., 1946, Preliminary report on trace elements investigations in the Sweepstakes Creek area, Koyuk district, Seward Peninsula, Alaska: U. S. Geol. Survey Trace Elements Invs. Rept. 25.

Killeen, $P_{0} L_{0}$, and White, M. G., 1950, Trace elements reconnaissance on the South Fork of Quartz Creek, northeastern Seward Peninsula, Alaska: U. S. Geol. Survey Trace Elements invs. Rept. 42, pt. 2 .

West, W. S., and Matzko, J. J., 1952, Reconnaissance for radioactive deposits in the Buckland-Kiwalik district, Candle quddrangle, Seward Peninsula, Alaska: U. S. Geol. Survey Trace Elements Invs. Rept. 49. 


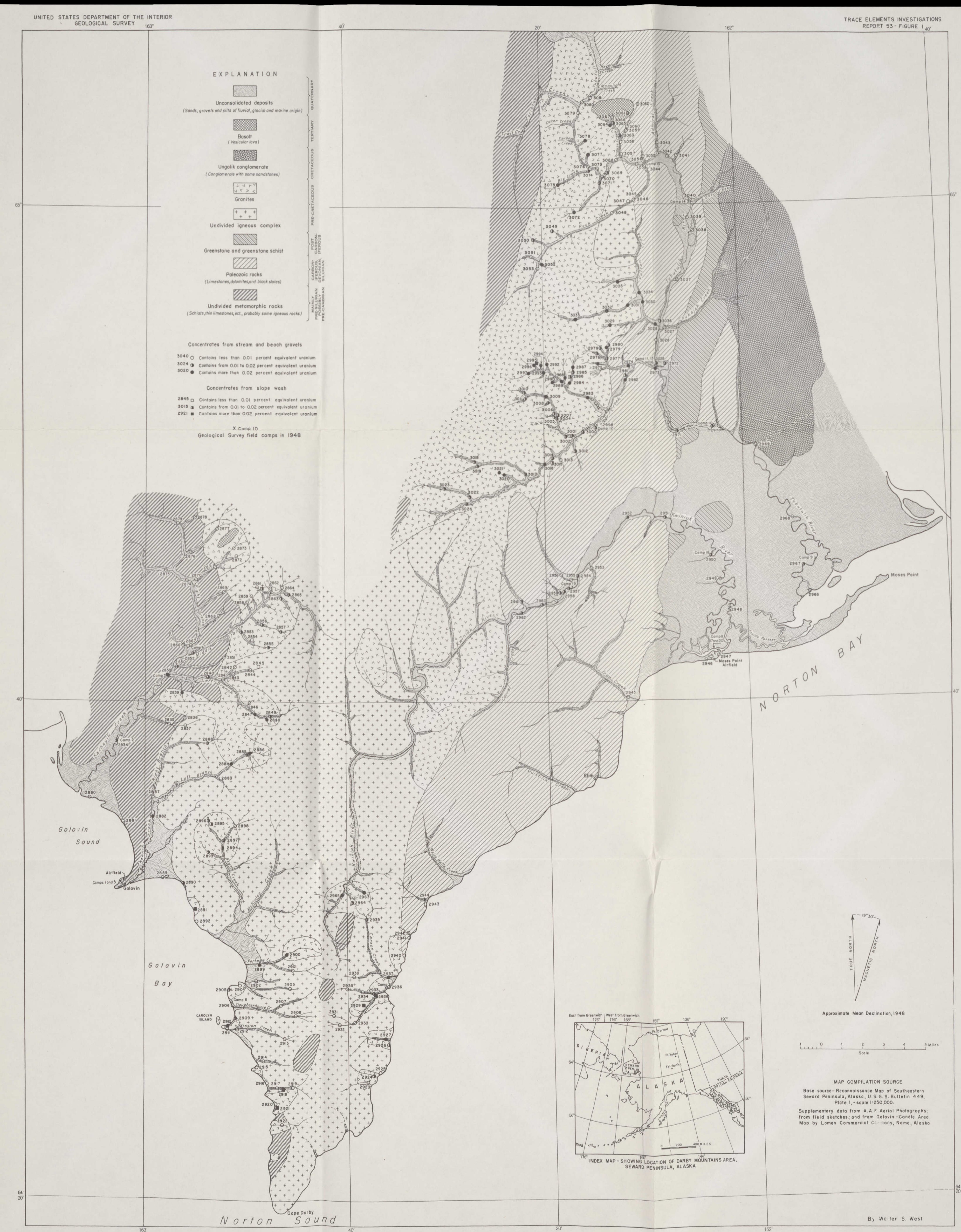



से 